\title{
ESTIMATION OF THE POSSIBILITY OF EXPANDING THE INSTRUMENT BASE FOR THE RAPID DETECTION OF FALSIFIED MEDICINAL PRODUCTS IN THE RIVNE REGION
}

\author{
S. Lebed, A. Nemchenko, O. Zdoryk
}

\begin{abstract}
Мета дослідження. Оцінка шляхів розширення приладової бази фотометричного обладнання для контролю якості лікарських засобів, обірунтування перспектив їх впровадження $і$ застосування у діяльності територіальної служби з лікарських засобів та контролю за наркотиками у Рівненській області.

Матеріали та методи. Використовувалися літературні дані, наукові публікаџії щзодо застосування фотометричних методів при контролі якості ЛЗ та власні дослідження контролю якості ЛЗ. У роботі використані методи системного аналізу, бібліосемантичний, узагальнення даних, при проведенні експериментальних досліджень використано метод абсорбиійної спектрофотометрії в інфрачервоній області.

Результати. В роботі проаналізовано ефективність застосування IЧ спектроскопії для контролю якості ЛЗ та виявлення їх фальсифікатів в рамках удосконалення сучасних підходів до протидії та боротьби з обігом ФЛЗ в Україні. Встановлено перспективу використання портативних раманівських спектрометрів для контролю якості ЛЗ, виходячи із їх переваг перед IЧ спектрофотометрією. Було проаналізовано визначений перелік Л3, щчо містять (азитроміцин, еритроміцин, ібупрофен, парацетамол, кларитроміцин, цефууроксим натрію), у тому числі жарознижувальних засобів та антибіотиків, які можуть бути використані для лікування ускладнень при COVID-19, методом абсорбиійної спектрофотометрії в інфрачервоній області із залученням приладової бази Начіонального університету водного господарства та природокористування і Рівненського державного гуманітарного університету міста Рівне.

Результати. В роботі вперше запропоновано залучення приладової бази вищих навчальних закладів для рутинного контролю якості ЛЗ та виявлення їх фальсифікатів територіальними лабораторіями $з$ контролю якості лікарських засобів на прикладі Рівненської області. Обтрунтовано необхідність впровадження та оснащення територіальних органів державного контролю якості лікарських засобів портативними приладами раманівської спектрометрії для проведення експресного, неруйнівного контролю якості ЛЗ.

Висновки. Актуальним для впровадження у роботу Державної служби з лікарських засобів та контролю за наркотиками є метод раманівської спектроскопії. Впровадження даного методу та обладнання дасть змогу підвищити ефективність інспектувань, а також значно скоротити терміни їх проведення. За результатами експериментальних досліджень на базі Національного університету водного господарства м. Рівне та Рівненського державного гуманітарного університету є доцільним і можливим залучення обладнання регіональних навчальних закладів та лабораторій для виявлення фальсифікатів і недопущення їх використання системою охорони здоров'я
\end{abstract}

Ключові слова: інфрачервона спектроскопія, раманівська спектроскопія, контроль якості лікарських засобів

Copyright (C) 2020, S. Lebed, A. Nemchenko, O. Zdoryk. This is an open access article under the CC BY license (http://creativecommons.org/licenses/by/4.0).

\section{Introduction}

One of the main tasks facing the State Service of Ukraine on Medicines and Drug Control is to take measures to ensure state quality control of medicines, which must include the selection and laboratory analysis of drug samples. It is well known that the threat of an increase in the number of counterfeits in pharmaceutical markets increases during epidemics, pandemics, natural disasters, catastrophes, when drug consumption increases significantly. During these periods, there is usually an increase in the workload of territorial laboratories for quality control of medicines, as it is observed today with the spread of acute respiratory disease COVID-19 caused by the coronavirus SARS-CoV-2. Increasing the workload can be solved in several ways - either by increasing the number of laboratories and instrumentation for drug control, or by significantly reducing the time for sample preparation and analysis of each sample.

At present, it is impossible to imagine the quality control of drugs without the use of physico-chemical methods that are optimal in terms of "price-quality" in terms of the accuracy of determining the identity of drugs in relation to the cost of the equipment. These methods are increasingly being implemented in basic pharmaceu- 
tical research and in the practice of pharmaceutical analysis for the identification and quantification of various groups of drugs, their standard samples and dosage forms $[1,2]$. The most optimal for use in pharmaceutical analysis, including for the detection of falsified drugs (FD) and API, today are photometric methods, namely: fluorimetry, atomic emission spectrometry, atomic absorption spectrometry, absorption spectrophotometric spectrophotometry absorption spectrophotometry in the ultraviolet (UV) and visible regions, Raman spectrometry, mass spectrometry, near-infrared spectrometry (NIRS). Photometric methods are widely used both in scientific research and to identify various counterfeits, for example, IR spectrophotometry is used to identify APIs, including broad-spectrum antibiotics (ampicillin, chloramphenicol, indomethacin) [3, 4]; the method of IR spectroscopy is used in the pharmacopoeial analysis of ranitidine hydrochloride tablets [5], there are studies of the application of the method in the analysis of medicinal plant raw materials [6]. Thus, photometric methods are widely used in establishing the authenticity of drugs and are used as a reliable method of detecting their falsification.

The aim of the article was to assess ways to expand the instrument base of photometric equipment for quality control of medicines, substantiation of prospects for their implementation and application in the activities of the territorial service on medicines and drug control in Rivne region.

\section{Research planning (methodology)}

To achieve this goal, the following tasks were identified: analysis and justification of the choice of photometric method; advantages of using IR and Raman spectrometry; conducting experimental research involving IR spectrophotometers of higher educational institutions in Rivne; identify the possibility of involving the instrument base of higher education institutions for the analysis of drugs in cases of heavy workload of laboratories of territorial services for medicines and drug control; summarizing the analysis and prospects for further research.

Experimental studies of drugs by IR spectrophotometry were planned on the basis of the National University of Water Management of Rivne and Rivne State University for the Humanities. The list of drugs and APIs was selected according to the lists of counterfeit drugs detected in Ukraine [7], in particular, the drug "Sumamed" manufactured by "Pliva" (Croatia) containing azithromycin $[8,9]$ and other drugs in demand.

\section{Materials and methods of research}

The research materials are literature data, scientific publications on the application of photometric methods in drug quality control and own research on drug quality control. The objects of experimental studies were azithromycin ("Sumamed", Croatia, series 424129), erythromycin ("Zinerit", the Netherlands, series 19A05 / 74), ibuprofen ("Ibuprom max", Poland, series U1904351), complex preparation of ibuprofen and paracetamol ("Nurofen Intensive, Great Britain, series HJ580"), clarithromycin ("Clerimed 500, Cyprus, series A2J053"), paracetamol ("Panadol", Spain, series,
F76W), cefuroxime sodium (“Axetin”, Cyprus, series C722AI). The following methods were used in the work: system analysis, bibliosemantic, data generalization, the method of absorption spectrophotometry in the infrared region using the instrument base was used in experimental research: IR Fourier spectrophotometers "IRAffinity-1S" manufactured by Shimadzu and "Nciolet iS5" manufactured by Fisher Scientific.

\section{Research results}

Infrared spectrometers such as UR-10, UR-20, Specord75 IR, Specord M40 (Carl Zeiss Jena, Germany), IR-Fourier spectrometers Nicolet 6700 (Thermo Fisher Scientific, USA) are most often used in the practice of pharmaceutical research [10] JASCO FT-IR 460 PLUS spectrometer (Pike Technologies, Madison, USA), as well as spectrometers IRPrestige-21, FTIR-8000S (Shimadzu, Japan). As a rule, helium-neon laser is used as a source of infrared radiation in such devices, the device also includes an optical system with mirrors and light dividers, a Michelson interferometer, an IR detector, and a processor. According to the technical characteristics, modern IR spectrometers have characteristics not less than: spectral range $7800-375 \mathrm{~cm}^{-1}$, resolution $1 \mathrm{~cm}^{-1}$, linearity of the ordinate (ASTM E1421) $0.1 \% \mathrm{~T}$, accuracy on the wave number $0.02 \mathrm{~cm}^{-1}$, scan speed 3 scans / $\mathrm{s}$. These characteristics meet the requirements of $\mathrm{SPhU}$ and are sufficient for pharmaceutical analysis.

Currently, IR spectrometers are very widely used, created and available databases of IR spectra for technical and food additives, drugs, poly- and monomers, surfactants, plasticizers, pesticides, solvents, petroleum products, toxic substances, steroids and other compounds, in the composition which includes one component. The literature is increasingly devoted to the publication of IR spectroscopy for the detection of FD, for example, samples of drugs of the steroid group [11], to identify derivatives of 1,4-benzodiazepines [12], qualitative and quantitative analysis of antitumor drugs derived from bis- $\beta$ - chloroethylamine [13], drugs based on benzenesulfamide derivatives in the presence of degradation products [14], nicotinic acid and its derivatives [15], pyrazole and salicylic acid derivatives [16], sildenafil [17], oxcarbazepine [18]. In the presence of an azido group having a characteristic band in the range of 4.69$4.71 \mu \mathrm{m}$, it is possible to identify azidothymidine [19], by a set of absorption bands in the high-, medium- and lowfrequency (less than $7.69 \mu \mathrm{m}$ ) regions - synthetic peptide compounds: thymogen, thymodepressin, neogene [20]. The IR spectrum of cordanum (adrenolytic substance) allows to identify it in biological material when performing forensic chemical studies [21].

A variant of IR spectrometry is the method of Raman spectrometry [22]. Raman spectrometry or Raman scattering obtains optical spectra when a substance is irradiated with near-infrared monochromatic laser radiation, in which the molecules of the substance are polarized and scatter light in the range from 2.5 to $5000 \mu \mathrm{m}[23,24]$. With such irradiation, the frequency of scattered radiation changes compared to the frequency of radiation incident on the object. Due to this, the analysis can take only 30 seconds. This method allows you to conduct research in addition to the identification of 
chemical compounds, as well as on-line monitoring of the reactions of organic synthesis and polymerization in real time; biochemical studies, such as cells in the wild; mineralogical research. That is why this method is increasingly used for drug analysis, including the detection of FD as described in [25]. A comprehensive study using a portable Raman IR spectrometer in the analysis of counterfeit solid dosage forms is given in the publication Dégardin K, Guillemain A, Roggo Y [26].

The main advantages of the method of Raman spectroscopy in comparison with IR spectrophotometry is that it:

- is non-destructive;

- can be made contactless and without opening the original packaging;

- usually does not require sample preparation;

- provides an opportunity to analyze samples in different physical states (solid materials, liquids, and in some cases also gases); minutes)

- the analysis is express (from seconds to

- has the possibility of remote non-contact analysis (for systems with optical fiber);

- has the ability to work with aqueous solutions (no overlap of the $\mathrm{H} 2 \mathrm{O}$ signal as in IR spectrometry);

- has the ability to obtain a signal from the depth of the sample, transparent in the selected range, with a penetration depth of from 0.1 to $10 \mu \mathrm{m}$ (depending on the frequency of the radiation source). Portable Raman spec- trometers, which are used both for input API control in pharmaceutical companies and for drug analysis, are becoming more and more widespread. Comparative characteristics of portable Raman spectrometers are given in Table 1.

These devices and the method of Raman spectrometry have proven themselves in the work of the Food and Drug Administration (FDA) and the US customs. The spectral information obtained by this method can be used to identify powders, liquids, gases, aqueous solutions and mixtures thereof. The device on the basis of KR can simultaneously detect up to 5 chemicals in the test sample. The method of Raman spectrometry is especially important for the detection of FD, as it allows you to quickly and quickly detect deviations from the parameters set by the manufacturer directly at the test site.

In order to confirm the possibility of involving the instrument base of higher education institutions, we conducted research on IR spectrometers of a certain list of drugs, including antipyretics and antibiotics that can be used to treat complications of COVID-19. Experimental studies were performed on spectrophotometers of the National University of Water Management in Rivne and Rivne State University for the Humanities. Samples of drugs were purchased in pharmacies in Rivne in the period from 13.03.2020-20.03.2020. The results are presented in Table 2. The table shows the analysis of the drugs determination, including the correlation coefficient $\mathrm{R}$, the determination limit (DL) and the limit of quantification (QDL).

Table 1

Comparative characteristics of portable Raman spectrometers

\begin{tabular}{|c|c|c|c|c|c|}
\hline Model & Manufacturer & $\begin{array}{c}\text { Excitation } \\
\text { wavelength }\end{array}$ & Spectral range & Resolution & Detector \\
\hline NanoRam, & B\&W Tek Taiwan & $785 \mathrm{~nm}$ & $176-2900 \mathrm{~cm}^{-1}$ & $9 \mathrm{~cm}^{-1}$ & $\begin{array}{c}\text { TE-Cooled Line- } \\
\text { ar CCD Array }\end{array}$ \\
\hline Progeny & Rigaku & $1064 \mathrm{~nm}$ & $200-2500 \mathrm{~cm}^{-1}$ & $8-11 \mathrm{~cm}^{-1}$ & $\begin{array}{c}512 \text { pixels, TE } \\
\text { cooled InGaAs }\end{array}$ \\
\hline Mira DS Advanced & Metrohm & $785 \mathrm{~nm}$ & $400-2300 \mathrm{~cm}^{-1}$ & $8-10 \mathrm{~cm}^{-1}$ & CCD-matrix \\
\hline $\begin{array}{c}\text { Vaya Handheld Raman } \\
\text { Spectrometer }\end{array}$ & Agilent & $830 \mathrm{~nm}$ & $300-2000 \mathrm{~cm}^{-1}$ & $12-20 \mathrm{~cm}^{-1}$ & CCD-matrix \\
\hline TruScan & Thermo Scientific & $785 \mathrm{~nm}$ & $250-2875 \mathrm{~cm}^{-1}$ & $8-10.5$ & CCD-matrix \\
\hline BRAVO & Bruker & $1064 \mathrm{~nm}$ & $300-3200 \mathrm{~cm}^{-1}$ & $8-10 \mathrm{~cm}^{-1}$ & $\begin{array}{c}\text { liquid nitrogen } \\
\text { cooled Germani- } \\
\text { um }\end{array}$ \\
\hline
\end{tabular}

Table 2

Analysis of drugs by IR spectrophotometry in the transmission mode

\begin{tabular}{|c|c|c|c|c|c|}
\hline \multirow{2}{*}{ Name of the substance } & \multirow{2}{*}{ Solvent, wave number, $\mathrm{cm}^{-2}$} & \multicolumn{4}{|c|}{ Characteristics } \\
\cline { 3 - 6 } & & $R^{2}$ & DL, mg & QDL, mg & $D, \%$ \\
\hline Azithromycin & Toluene, $1700-1750$ & 0.999 & 1.0 & 0.2 & 98 \\
\hline Erythromycin & $\mathrm{KBr}, 1680-1750$ & 0.998 & 0.006 & 0.02 & 99 \\
\hline Ibuprofen & Chloroform, 1465-1814 & 0.998 & $0.78 \mu \mathrm{g} / \mathrm{ml}$ & $2.6 \mu \mathrm{g} / \mathrm{ml}$ & 98 \\
\hline $\begin{array}{c}\text { Ibuprofen and } \\
\text { paracetamol }\end{array}$ & $\begin{array}{c}\mathrm{KBr}, 1680-1785 \text { for ibuprofen } \\
\text { and } 1531-1631 \text { for paraceta- } \\
\text { mol }\end{array}$ & 0.999 & $0.001 \mathrm{mg} / \mathrm{g}$ & $0.013 \mathrm{mg} / \mathrm{g}$ & 98 \\
\hline Clarithromycin & $\mathrm{KBr}, 1660-1780$ & 0.996 & 0.01 & 0.03 & 98 \\
\hline Paracetamol & $\mathrm{KBr}, 1001-1802$ & 0.999 & 0.005 & 0.019 & 99 \\
\hline Cefuroxime sodium & $\mathrm{KBr}, 1470-1610$ & 0.999 & 0.16 & 0.6 & 99 \\
\hline
\end{tabular}




\section{Discussion of research results}

According to the results of research of drug analysis by IR spectrophotometry in the transmission mode, it was found that the spectrometers of educational institutions in Rivne meet the requirements of SPhU and the indicator of the limit of determination significantly outweighs the chemical methods of determination. The main disadvantage of IR spectrophotometry of drugs, in our opinion, is that they require sample preparation (deformation, destruction and dissolution, especially for the solid phase). This requires additional legal insurance when transferring samples from territorial services for medicines and drug control to another laboratory (sealing of samples of seized drugs, photoregistration of sample preparation methods, spectrum sampling process, its comparison with the reference, etc.). Comparisons of the obtained results with the results of other researchers indicate that some of the studied substances with the help of our equipment are determined with greater accuracy [27-29]. Deviations of API content correspond to content tolerances in drugs (5-10\%). According to the results of experimental studies by IR spectrophotometry, FD were not detected, which indicates the quality of drugs sold in pharmacies in Rivne. Since these studies were the first to use the equipment of Rivne institutions of higher education for this task, we see further prospects in improving the methods of IR spectrometry to use them for such specific tasks.

\section{Conclusions}

Today, IR spectrophotometry in terms of reliability, cost of one test and accuracy is one of the first places in the analysis of API and drugs. From the experience of the State Service for Medicines and Drug Control in Rivne region it is known that it is necessary to introduce new, express and mobile methods of detecting counterfeit drugs without any damage to their packaging. That is why in Ukraine it is necessary to implement two significant projects that can minimize and even prevent the entry of counterfeits on the Ukrainian pharmaceutical market, which are associated with the use of new technologies in research. Namely, the introduction of codification of 2D drug packaging - bar code and equipping territorial bodies of state quality control of medicines with portable devices, for example, as illustrated in the article - Raman spectrometers to detect substandard and counterfeit drugs. The use of Raman spectroscopy will not only significantly reduce the time of inspections, but also significantly increase their efficiency. In addition, since this analysis is performed without damaging the original packaging of the medicine, the use of such a device will significantly save money of businesses, because for a normal laboratory analysis, as a rule, requires several packages of drugs.

According to the results of experimental research on the basis of the National University of Water Management of Rivne and Rivne State University for the Humanities, it is expedient and possible to involve the equipment of regional educational institutions and laboratories to detect counterfeits and prevent their use by the health care system.

\section{Conflict of interest}

Authors declare no conflict of interest.

\section{References}

1. Arzamascev, A. P., Pechennikov, V. M., Rodionova, G. M. et. al. (2000). Analiz lekarstvennykh smesei. Moscow: Kompaniia Sputnik, 275.

2. Pogodina, L. I. (1985). Analiz mnogokomponentnykh lekarstvennykh form. Minsk: Vysshaia shkola, 240.

3. Baranova, N. V., Feofanova, M. A. (2011). Primenenie metoda infrakrasnoi spektroskopii v analize lekarstvennykh sredstv. Vestnik Tverskogo gosudarstvennogo universiteta. Seriia Khimiia, 12, 49-56.

4. Aleksandrova, T. V., Kriuchkova, L. K., Budanova, N. A., Grigoreva, I. V. (2016). Aktualnost primeneniia metoda IKspektrometrii pri opredelenii podlinnosti lekarstvennykh sredstv $\mathrm{v}$ usloviiakh ispytatelnoi laboratorii po kontroliu kachestva lekarstvennykh sredstv. Mezhdunarodnii zhurnal prikladnykh i fundamentalnykh issledovanii, 10 (4), 609-613.

5. Stepanova, E. V., Dorofeev, V. L., Arzamascev, A. P. (2008). Ispolzovanie metoda IK- spektrofotometrii bez vydeleniia deistvuiuschego veschestva dlia identifikacii lekarstvennykh sredstv ranitidina gidrokhlorida. Vestnik VGU. Seriia: Khimiia, Biologiia, Farmaciia, 2, 153-158.

6. Trineeva, O. V., Rudaia, M. A., Gudkova, A. A., Slivkin, A. I. (2018). Primenenie IK-spektroskopii v analize lekarstvennogo rastitelnogo syria. Vestnik VGU. Seriia: Khimiia, Biologiia, Farmaciia, 4, 187-194.

7. Ofitsiinyi Sait Derzhavnoi sluzhby Ukrainy z likarskykh zasobiv ta kontroliu za narkotykamy. Available at: https://www.dls.gov.ua/

8. Korostashova, I. M. (2012). Borotba proty kontrafaktsii likarskykh zasobiv v Ukraini (pytannia normatyvno-pravovoho zabezpechennia: kryminalne zakonodavstvo ta zakonodavstvo z pytan intelektualnoi vlasnosti). Visnyk Akademii mytnoi sluzhby Ukrainy. Seriia: «Pravo», 2 (9), 65-71.

9. Derzhavna Farmakopeia Ukrainy. Vol. 1. Kharkiv: Derzhavne pidpryiemstvo «Ukrainskyi naukovyi farmakopeinyi tsentr yakosti likarskykh zasobiv», 1128.

10. Wilson, B. K., Kaur, H., Allan, E. L., Lozama, A., Bell, D. (2017). A New Handheld Device for the Detection of Falsified Medicines: Demonstration on Falsified Artemisinin-Based Therapies from the Field. The American Journal of Tropical Medicine and Hygiene, 96 (5), 1117-1123. doi: http://doi.org/10.4269/ajtmh.16-0904

11. Arzamascev, A. P., Senov, P. L. (1978). Standartnye obrazcy lekarstvennykh veschestv. Moscow: Medicina, 248.

12. Zhiliaeva, M. A., Trofimov, A. R., Ramenskaia, G. V. et. al. (1996). Identifikaciia lekarstvennykh sredstv gruppy 1,4benzodiazepina po elektronnym i kolebatelnym spektram pogloscheniia. Farmaciia, 45 (5), 35-36.

13. Kozlov, N. E., Sbezhneva, V. G. (1980). Ispolzovanie IK-spektroskopii dlia ocenki kachestva preparatov - proizvodnykh khloretilamina. Farmaciia, 29 (1), 33-34.

14. Lazarian, D. S. (1980). IK spectroscopia v analyse necotoryh proizvodnyh benzosulfonamida. Farmaciia, 29 (2), $36-38$.

15. Mynka, A. F., Liuta, M. L. (1985). Vykorystannia IK-spektroskopii dlia identifikacii nikotynovoi kysloty ta ii pohidnyh. Farmacevt, 4, 40-43. 
16. Belikov, V. G. (2000). Identifikaciia preparatov v lekarstvennykh formakh metodom proizvodnoi spektrofotometrii. Farmaciia, 49 (1), 23-25.

17. Lanzarotta, A., Lorenz, L., Batson, J. S., Flurer, C. (2017). Development and implementation of a pass/fail field-friendly method for detecting sildenafil in suspect pharmaceutical tablets using a handheld Raman spectrometer and silver colloids. Journal of Pharmaceutical and Biomedical Analysis, 146, 420-425. doi: http://doi.org/10.1016/j.jpba.2017.09.005

18. Ma, B., Wang, L. (2015). An application of rapid detection technologies in a national regulatory laboratory setting: Differentiating imported and domestic drug products of oxcarbazepine using handheld Raman, near infrared, and portable FTIR analyzers. American Pharmaceutical Review, 18 (2).

19. Nesterov, V. V., Titova, A. I., Evtushenko, I. S. (1991). Ispolzovanie UF spektrofotometrii v kontrole kachestva azidotimidina. Farmaciia, 40 (3), 30-32.

20. Kashirin, D. M., Sibilev, A. V., Beloborodov, V. L. et. al. (2000). Primeneniie IK-spektroskopii dlia identifikaciii syntertisheskih peptydnyh preparatov timogena, tymodepressina i neogena. Khimiko-farmacevticheskii zhurnal, 34 (11), 48-51.

21. Volgram, E. N. (1988). Primenenije IES-spectrofotometrii dlia ustanovlenija kordanuma v trupnom materiale. Sudeb.med. Ekspertiza, 31 (2), 34-35.

22. Derzhavna Farmakopeia Ukrainy. T. 2. Kharkiv: Derzhavne pidpryiemstvo «Ukrainskyi naukovyi farmakopeinyi tsentr yakosti likarskykh zasobiv», 52-55.

23. The State Pharmacopoeia of the Russian Federation. Vol. 1-3 (2015). Moscow. Available at: http://femb.ru/feml

24. Vickers, S., Bernier, M., Zambrzycki, S., Fernandez, F. M., Newton, P. N., Caillet, C. (2018). Field detection devices for screening the quality of medicines: a systematic review. BMJ Global Health, 3 (4), e000725. doi: http://doi.org/10.1136/bmjgh-2018000725

25. Frosch, T., Wyrwich, E., Yan, D., Domes, C., Domes, R., Popp, J., Frosch, T. (2019). Counterfeit and Substandard Test of the Antimalarial Tablet Riamet ${ }^{\circledR}$ by Means of Raman Hyperspectral Multicomponent Analysis. Molecules, 24 (18), 3229. doi: http://doi.org/10.3390/molecules24183229

26. Dégardin, K., Guillemain, A., Roggo, Y. (2017). Comprehensive Study of a Handheld Raman Spectrometer for the Analysis of Counterfeits of Solid-Dosage Form Medicines. Journal of Spectroscopy, 2017, 1-13. doi: http://doi.org/10.1155/2017/3154035

27. Arzamascev, A. P., Lutceva, T. Iu., Sadchikova, N. P. (2001). Metody analiza i standartizaciji lekarstvennyh sredstv proizvodnyh barbiturovoi kisloty(obzor). Khimiko-farmacevticheskii zhurnal, 35 (8), 47-51.

28. Lutceva, A. I., Maslov, L. G. (1999). Metody kontrolia i standartizacii lekarstvennykh preparatov, soderzhaschikh vodorastvorimye vitaminy (obzor). Khimiko-farmacevticheskii zhurnal, 33 (9), 30-37.

29. Lutceva, A. I., Maslov, L. G., Seredenko, V. I. (2001). Metody kontrolia i standartizacii lekarstvennykh preparatov, soderzhaschikh zhirorastvorimye vitaminy. Khimiko-farmacevticheskii zhurnal, 35 (10), 41-46.

Received date 20.05.2020

Accepted date 18.06.2020

Published date 30.06.2020

Serhii Lebed, Postgraduate Student, Department of Organization and Economics, National University of Pharmacy, Pushkinska str., 53, Kharkiv, Ukraine, 61002, Chief, State Service for Medicines and Drug Control in the Rivne region, 16 Lypnia str., 38, Rivne, Ukraine, 33028

E-mail: s.lebed2016@gmail.com

Alla Nemchenko, Doctor of Pharmaceutical Sciences, Professor, Head on Department, Department of Organization and Economics, National University of Pharmacy, Pushkinska str., 53, Kharkiv, Ukraine, 61002 E-mail: asnemchenko@ukr.net

Aleksandr Zdoryk, Doctor of Pharmaceutical Sciences, Associate Professor, Department of Quality, Standardization and Certification of Medicines, Institute for Advanced Training of Pharmacy Specialists, Zakhystnykiv Ukrainy sq., 17, Kharkiv, Ukraine, 61001

E-mail: oleksandr_zdoryk@ukr.net 